\title{
Pengembangan Aktivitas Pembelajaran Mengasosiasi Berbasis Media Gambar Berseri Dalam Meningkatkan Proses Kognitif Siswa
}

\author{
AA Gede Agung1 , IW Widiana ${ }^{2}$, NK Savitri Indrasuari ${ }^{3 *}$ \\ 1 Jurusan Pendidikan Guru Sekolah Dasar. Universitas Pendidikan Ganesha, Indonesia \\ 2 Jurusan Pendidikan Guru Sekolah Dasar. Universitas Pendidikan Ganesha, Indonesia \\ ${ }_{3}^{3}$ Jurusan Pendidikan Guru Sekolah Dasar. Universitas Pendidikan Ganesha, Indonesia
}

\begin{abstract}
Abstrak
The purpose of this research is to know the difference of cognitive process between group of students using learning associate activity based on media of serial image in scientific approach and students who learn to use conventional learning activity in fourth grade students even semester of academic year 2016/2017 at elementary school of Sukasada district. This type of research is a quasi experiment with post test only control group design. The population of this study amounted to 255 students. While the sample amounted to 54 students. The data collected in this research is cognitive process test using 19 essay test. The hypothesis was tested using t-test inferential statistics. The results showed that there were significant differences in cognitive processes between groups of students using learning associate activities based on serialized media in scientific approach and students learning using conventional learning activities ( $\left.t_{\text {count }}=8,58>t_{\text {table }}=2,00665\right)$.
\end{abstract}

Keywords:

learning activity, scientific approach, cognitive process

\section{Pendahuluan}

Dunia pendidikan Indonesia di tahun 2013 ini diwarnai oleh isu utama, yaitu perubahan kurikulum. Kurikulum merupakan sebuah unsur paling penting untuk menggerakkan sistem pendidikan yang ada di suatu Negara, termasuk di Indonesia (Putra, 2016). Pendidikan di Indonesia sudah beberapa kali dilaksanakan penyempurnaan dan perbaikan kurikulum. Perubahan kurikulum didasari pada kesadaran bahwa perkembangan dari perubahan yang terjadi menuntut perlunya perbaikan sistem pendidikan ( Apriliani, 2016). Kurikulum akan secara terus menerus mengalami perubahan untuk efektivitas kegiatan pembelajaran melalui perubahan isi, kegiatan, dan perbaikan proses pendidikan yang direncanakan (Widyani, Suwatra, \& Widiana, 2015). Kurikulum yang belakangan hebat diperdebatkan di antara birokrat pendidikan dan praktisi pendidikan lainnya hingga kini belum jelas namanya. Kurikulum 2013 merupakan kurikulum yang diterapkan oleh pemerintah untuk menggantikan kurikulum 2006 yang sering disebut dengan Kurikulum Tingkat Satuan Pendidikan (KTSP). Rancangan kurikulum 2013 bersifat sentralistik, yang mana pemerintah pusat dan daerah memiliki kendali kualitas dalam pelaksanaan kurikulum di tingkat satuan pendidikan (Suryantari \& Sumantri, 2014). Pemerintah menyiapkan semua komponen kurikulum sampai buku teks dan pedoman. Termasuk penyusunan silabus. Kurikulum 2013 disiapkan untuk mencetak generasi yang siap didalam menghadapi masa depan. Karena itu kurikulum disusun untuk mengantisipasi perkembangan masa depan.

Salah satu perubahan yang mendasar terjadi di tingkat sekolah dasar yaitu terkait dengan sistem pembelajaran berubah menjadi pembelajaran tematik integratif. Pembelajaran tematik akan diwajibkan di sekolah dasar baik untuk kelas-kelas awal maupun kelas-kelas tinggi (Kristiantari, 2014). Kurikulum 2013 bersifat tematik-integratif yang mengambil pokok bahasan pelajaran berdasarkan tema dengan menggabungkan beberapa pelajaran menjadi satu.

Pelaksanaan pembelajaran pada kurikulum 2013 mengamanatkan pendekatan saintifik atau ilmiah dalam pelaksanaannya. Pendekatan saintifik (Scientific Appoachi) dalam pembelajaran sebagaimana dimaksud meliputi mengamati, menanya, mencoba/mengumpulkan informasi, mengasosiasi/mengolah informasi, mengkomunikasikan dan mencipta untuk semua

\footnotetext{
* Corresponding author.

E-mail Addresses: Agungtps2056@gmail.com (AA Gede Agung), wayan_widiana@yahoo.co.id (IW Widiana), nikadeksavitriindrasuari@gmail.com (NK Savitri Indrasuari)
} 
mata pelajaran. Pembelajaran berbasis pendekatan saintifik diharapkan dapat memberikan pemahaman kepada siswa dalam mengenal dan memahami berbagai materi yang diberikan dengan menggunakan metode ilmiah ( Oktafianti, 2015). Kurniasih dan Sani (2014:33) menyatakan,

Karakteristik pendekatan saintifik antara lain sebagai berikut: 1) berpusat pada siswa, 2) melibatkan proses sains dalam mengontruksi konsep, hukum atau prinsip, 3) melibatkan prosesproses kognitif yang potensial dalam merangsang perkembangan intelek, khususnya ketrampilan berpikir tingkat tinggi siswa, 4) dapat mengembangkan karakter siswa.

Saat ini, pemerintah sudah mulai mengimplementasikan Kurikulum 2013 secara terbatas melalui beberapa sekolah percobaan (pilot project) mulai dari tingkat sekolah dasar (SD) sampai dengan tingkat sekolah menengah atas (SMA/SMK (Subagia \& Wiratma, 2016)). Penerapan Kurikulum 2013 di Kabupaten Buleleng, terdapat 20 sekolah yang telah diputuskan tetap menerapkan Kurikulum 2013 (K13) setelah menerima surat edaran dari Kementerian Pendidikan Dasar \& Menengah dan Kebudayaan tentang sekolah-sekolah yang dianggap telah siap melaksanakan K13 untuk tetap melanjutkannya (Tribun Bali, 2014). Tujuh diantaranya merupakan sekolah di tingkat dasar. Ketujuh sekolah tersebut di antaranya, SDN 3 Banjar Jawa, SDN 4 Kaliuntu, SDN 4 Kampung Baru, SDN 6 Pejarakan, SDN 9 Busungbiu, SDN 4 Banyuasri dan SD Lab.

Hampir seluruh sekolah dasar yang ada di kecamatan-kecamatan di wilayah Kabupaten Buleleng mulai bertahap menerapkan Kurikulum 2013, salah satunya adalah kecamatan Sukasada. Berdasarkan hasil obervasi yang dilakukan pada tanggal 30 Januari, 1 dan 2 Februari 2017, dapat diketahui terdapat sembilan sekolah yang telah menerapkan kurikulum 2013 di Kecamatan Sukasada, namun hanya diterapkan pada kelas I dan kelas IV. Sekolah tersebut diantaranya: SDN 1 Sukasada, SDN 1 Gitgit, SDN 1 Panji, SDN 1 Selat, SDN 2 Ambengan, SDN 2 Sukasada, SDN 2 Padang Bulia, SDN 3 Kayu Putih, dan SDN 3 Sambangan.

Berkaitan dengan perubahan kurikulum, guru diharapkan dapat menciptakan suasana kelas yang besar dalam pengelolaan kelas karena guru sebagai penanggung jawab dalam proses kegiatan belajar mengajar di dalam kelas (Ariningsih, Suwatra, \& Widiana, 2015). Mengajar bukan hanya menyampaikan materi pembelajaran, akan tetapi suatu proses mengubah sikap siswa sesuai dengan tujuan yang diharapkan (Putra, 2015). Diharapkan juga pada kurikulum 2013 hasil belajar siswa memiliki rata-rata di atas Kriteria Ketuntasan Minimal (KKM). Namun pada kenyataannya masih ditemukan hasil belajar siswa masih rendah atau dibawah KKM. Hal tersebut tercantum dari hasil ulangan tengah semester ganjil tahun pelajaran 2016/2017 dapat dilihat pada tabel 1.

Tabel 1. Rata-rata Hasil Ulangan Tengah Semester Ganjil Tahun Pelajaran 2016/2017

\begin{tabular}{llll}
\hline No & Sekolah & $\begin{array}{l}\text { Jumlah } \\
\text { Siswa }\end{array}$ & $\begin{array}{l}\text { Rata-Rata } \\
\text { Kelas }\end{array}$ \\
\hline 1 & SDN 1 Sukasada & 25 & 72,56 \\
2 & SDN 1 Gitgit & 17 & 76,47 \\
3 & SDN 1 Selat & 34 & 74,52 \\
4 & SDN 1 Panji & 36 & 59,05 \\
5 & SDN 2 Sukasada & 26 & 69,38 \\
6 & SDN 2 Ambengan & 27 & 63,18 \\
7 & SDN 2 Padang Bulia & 28 & 68,28 \\
8 & SDN 3 Sambangan & 32 & 72,75 \\
9 & SDN 3 Kayuputih & 30 & 67,76 \\
\hline
\end{tabular}

(sumber: wali kelas IV di sekolah rintisan kurikulum 2013 di Kecamatan Sukasada)

Data tersebut menunjukkan bahwa lima sekolah dasar rintisan kurikulum 2013 di Kecamatan Sukasada nilai rata-rata dari ulangan tengah semester siswa masih rendah. Melalui hasil observasi dan wawancara dengan wali kelas IV di sekolah rintisan kurikulum 2013 Kecamatan Sukasada, kelima dari sembilan sekolah tersebut hampir memiliki permasalahan yang sama yaitu masih belum optimalnya hasil belajar siswa sehingga masih dibawah KKM. Penyebab rendahnya hasil belajar siswa dikarenakan sebagai berikut: 1) kurangnya media pembelajaran pada saat proses belajar mengajar. Selama proses pembelajaran guru cenderung hanya menggunakan buku paket. 2) guru belum secara penuh menerapkan pendekatan saintifik dalam pembelajaran. Pada saat mengajar, guru kurang lengkap dan kurang benar dalam menerapkan langkah-langkah pendekatan saintifik. Guru tidak pernah menerapkan langkah mengasosiasi dalam pembelajaran, sehingga siswa belum mampu menemukan keterkaitan suatu 
informasi dengan informasi lainnya, 3) guru dan siswa belum terbiasa menggunakan kurikulum 2013 ini, 4) guru masih banyak menggunakan metode ceramah, walaupun terkadang juga menggunakan metode diskusi dan tanya jawab. Jadi selama tiga tahun terakhir ini, kurikulum 2013 yang sudah diterapkan di beberapa sekolah belum menunjukkan adanya variasi ataupun aktivitas pembelajaran yang berkembang, seolah-olah kurikulum 2013 dengan kurikulum 2006 (KTSP) terlihat mirip. Hal ini juga sejalan dengan hasil penelitiannya (Dewi, Sumantri, \& Widiana, 2015) yang menyatakan bahwa sebagian besar sekolah belum siap melaksanakan kurikulum 2013 karena beberapa hal, antara lain masalah kesiapan buku, sistem penilaian, penataran guru, pendampingan guru, dan pelatihan kepala sekolah. Hasil penelitian Krissandi (2013) juga menunjukkan bahwa kendala-kendala yang dialami guru SD dalam implementasi kurikulum 2013 berasal dari pemerintah, institusi, guru, orang tua, dan siswa. Ariningsih, Suwatra, \& Widiana (2015) menyatakan bahwa proses pembelajaran didalam kelas diarahkan kepada kemampuan peserta didik untuk menghafal informasi, otak peserta didik dipaksa untuk mengingat dan menimbun berbagai informasi tanpa dituntut untuk memahami informasi diingatnya itu untuk kehidupan seharihari.

Temuan tersebut didukung oleh (Widyani, Suwatra \& Widiana, 2017) yang mengemukakan bahwa kendala dalam proses pembelajaran adalah keterbatasan materi atau fasilitas pendukung yang mendukung pelajaran, kesulitan dalam mengubah pola pikir semua orang di sekolah menuju perubahan kurikulum, terutama siswa kelas 4 dan 5 dan kesulitan guru dalam memilih media pembelajaran.

Masalah di atas perlu dicarikan solusi agar pembelajaran yang dilaksanakan dapat memberikan hasil belajar yang optimal. Diperlukan suatu ketrampilan baru yang berguna mengasah kemampuan menalar siswa agar pengetahuan yang didapat tidak hanya sebatas kemampuan hafalan saja. Suatu ketrampilan baru yang dimaksud adalah kemampuan penalaran (mengasosiasi) yang merupakan salah satu komponen pendekatan saintifik. Wartini, Lasmawan, \& Marhaen (2014) menyatakan bahwa pendekatan ini menuntut siswa yang aktif dalam melakukan keterampilan ilmiah (bukan gurunya). Pembelajaran yang menuntut siswa yang aktif dalam melakukan keterampilan ilmiah tentunya membuat interaksi siswa dengan guru maupun siswa dengan siswa akan terjalin dengan efektif.

Proses mengolah informasi akan lebih efektif dan bermakna apabila disertai dengan media pembelajaran. Kenyataannya,sampai saat ini pemanfaatan media dalam pembelajaran belum dilakukan secara maksimal oleh guru (Sumantri, 2017). Tegeh dalam Ariningsih (2015) menyatakan bahwa, "Media pembelajaran sangat penting untuk diketahui dan dipahami oleh semua orang yang langsung maupun tak langsung berhubungan dengan pembelajaran". Media pembelajaran dapat mewakili guru dalam menyampaikan pesan secara lebih teliti, jelas dan menarik. Dengan menggunakan media dalam pembelajaran siswa akan lebih terangsang dalam mengikuti pelajaran (Aristana, Kusmariyatni, \& Widiana, 2014). Penggunaan media pembelajaran juga sangat diharapkan untuk membantu siswa menpelajari objek, suara, proses, peristiwa atau lingkungan yang sulit dihadirkan ke dalam kelas. Oleh karena itu, guru hendaknya dapat memilih media yang tepat sesuai dengan materi dan karakteristik siswa dalam proses pembelajaran.

Pada saat aktivitas mengasosiasi yang dilakukan oleh siswa, akan dibantu menggunakan media yang membuat siswa lebih tertarik terhadap proses pembelajaran, yaitu media gambar berseri. Menurut Musfiroh (dalam Almasitoh, 2013) "media gambar berseri merupakan sejumlah gambar yang menggambarkan suasana yang sedang diceritakan dan menunjukkan adanya kesinambungan antara gambar yang satu dengan lainnya". Hal ini diperkuat oleh Mahendra, Arini, \& Sumantri (2016) yang menemukan bahwa ada perbedaan keterampilan berbicara siswa yang mengikuti pembelajaran menggunakan pendekatan saintifik berbantuan media gambar berseri dan siswa yang mengikuti pembelajaran menggunakan pembelajaran konvensional pada siswa kelas IV SD Negeri 1 Sangsit. Hasil penelitian menunjukkan bahwa rata-rata skor yang diperoleh kelompok siswa yang belajar dengan menggunakan pendekatan saintifik berbantuan media gambar berseri adalah 81,41 lebih besar daripada rata-rata skor kelompok siswa yang belajar menggunakan pembelajaran konvensional, yaitu sebesar 69,11. Sumerti, Putra, \& Suardika, (2014) juga menemukan bahwa terdapat perbedaan yang signifikan keterampilan menulis pada pelajaran bahasa Indonesia antara siswa yang dibelajarkan menggunakan model pembelajaran kooperatif tipe Concept Sentence berbantuan gambar berseri dengan siswa yang dibelajarkan menggunakan pembelajaran konvensional pada kelas SDN 22 Dauh Puri Denpasar tahun pelajaran 2013/2014. Ketrampilan menulis kelompok siswa yang dibelajarkan menggunakan model pembelajaran kooperatif tipe NHT dengan bantuan gambar berseri lebih tinggi daripada ketrampilan menulis kelompok siswa yang dibelajarkan menggunakan model pembelajaran konvensional. Hasil penelitian tentang media gambar berseri menyarankan bahwa penggunaan media gambar berseri dengan metode TGT dapat meningkatkan keaktifan dan motivasi siswa dalam pembelajaran menulis eksposisi, itu disebabkan media gambar bersifat konkret yang artinya lebih realistis menunjukkan pokok masalah (Puspitarukmi, Fuady, \& Wardani, 2014). Selian itu Sugiarti, Putra, \& Abadi (2014) menemukan bahwa 
penerapan model pembelajaran TTW (Think Talk Write) berbantuan media gambar berseri berpengaruh terhadap hasil belajar bahasa Indonesia siswa kelas V SD Gugus 1 Kecamatan Kediri,Tabanan Tahun Ajaran 2013/2014. Berdasarkan hasil penelitian tersebut, media gambar berseri sangat cocok untuk anak sekolah dasar, karena dalam pembelajaran siswa SD perlu benda-benda konkret agar mudah dipahami ketika penyampaian materi. Begitu juga dengan harganya yang murah dan mudah didapatkan tanpa peralatan khusus.

Melalui aktivitas pembelajaran mengasosiasi berbasis media gambar berseri ini, siswa mampu mengolah informasi yang telah diperolehnya dengan merangkai media gambar berseri tersebut. Siswa juga cenderung tidak akan bosan dengan proses pembelajaran yang terjadi di kelas dan akan lebih termotivasi untuk belajar. Meningkatnya motivasi belajar siswa juga akan berpengaruh terhadap kemampuan menalar siswa dan proses kognitif siswa. Anderson dan Kratwohl pada Taksonomi Bloom Revisi $(2010 ; 100)$ menyatakan,

Terdapat hasil belajar kognitif yaitu dimensi proses kognitif: (1) Mengingat: mengambil pengetahuan dari memori jangka panjang; (2) Memahami: mengkontruksikan makna dari materi pembelajaran, termasuk apa yang diucapkan, ditulis, dan digambar oleh guru; (3) Mengaplikasikan: menerapkan atau menggunakan suatu prosedur dalam keadaan tertentu; (4) Menganalisis: memecah-mecah materi jadi bagian-bagian penyusunannya dan menentukan hubungan-hubungan antar bagian itu dan hubungan antara bagian-bagian tersebut dan keseluruhan struktur atau tujuan; (5) Mengevaluasi: mengambil keputusan berdasarkan kriteria dan/atau standar; (6) Mencipta: memadukan bagian-bagian untuk membentuk sesuatu yangt baru dan koheren atau untuk membuat suatu produk yang orisinal.

Untuk mengukur proses kognitif tersebut diperlukan suatu tes untuk mengetahui tingkat keberhasilan siswa yang disebut dengan hasil belajar. Hasil belajar itu yang digunakan guru untuk menentukan apakah siswa tersebut sudah berhasil dalam pembelajaran atau perlu melakukan remidial kembal. Tidak hanya bertujuan untuk mencapai peningkatan di hasil akhir, tetapi termasuk juga pada proses pencapaian hasil.

Berdasarkan pemaparan di atas, sangat menarik untuk diteliti bagaimana proses kognitif siswa dengan mengembangkan aktivitas belajar berbasis media gambar berseri pada Kurikulum 2013. Karena dalam implementasi Kurikulum 2013 menggunakan pendekatan saintifik, maka mengasosiasi/menalar merupakan salah satu komponen yang akan diteliti. Untuk itu diadakan suatu penelitian dengan judul "Pengaruh Aktivitas Pembelajaran Mengasosiasi Berbasis Media Gambar Berseri dalam Pendekatan Saintifik Terhadap Proses Kognitif pada Siswa Kelas IV Semester Genap Tahun Pelajaran 2016/2017 Di SD Kecamatan Sukasada".

\section{Metode Penelitian}

Artikel ini dibuat dari hasil penelitian semu dengan rancangan penelitian post test only control group design. Penelitian ini dilaksanakan di SD Kecamatan Sukasada Kabupaten Buleleng pada rentang waktu semester genap tahun pelajaran 2016/2017. Populasi dalam penelitian ini adalah siswa kelas IV sekolah rintisan Kurikulum 2013 di Kecamatan Sukasada, Kabupaten Buleleng. Banyaknya siswa seluruhnya 255 orang siswa. Sampel diambil dengan cara random sampling yang berjumlah 54 orang terbagi menjadi dua kelas.

Data yang ingin diketahui dalam penelitian ini adalah proses kognitif siswa dalam pembelajaran tematik di sekolah dasar. Metode pengumpulan data yang digunakan adalah tes essay yang berjumlah 19 butir yang sudah divalidasi secara konten dan empirik. Secara konten, tes yang digunakan sudah memenuhi unsur kompetensi dasar dengan kalimat yang baik sesuai dengan perkembangan psikologis anak usia kelas IV sekolah dasar. Sedangkan analisis validasi empiriknya yang ditinjau dari analisis konsistensi interal tes terhadap 19 butir tes, dan semua tes yang diujikan dinyatakan valid. Analisis daya beda butir tes didapatkan 14 butir berkualifikasi cukup baik dan 5 butir berkualifikasi kurang baik. Analisis tingkat kesukaran tes didapatkan 14 butir tes berada pada kriteria sedang dan 5 butir tes termasuk dalam kriteria mudah. Analisis reliabilitas tes menyatakan bahwa reliabilitas tes berada pada kualifikasi tinggi $(0,76)$. Data hasil tes proses kognitif siswa diambil dengan memberikan post-test pada siswa setelah selesai menerapkan aktivitas pembelajaran mengasosiasi berbasis media gambar berseri dan menerapkan aktivitas pembelajaran konvensional.

Hipotesis penelitian ini dianalisis dengan menggunakan uji-t. Namun untuk memberikan gambaran terhadap sebaran data penelitian ini menggunakan analisis dekriptif dengan kriteria rata-rata ideal dan standar deviasi ideal seperti pada tabel 2 . 
Tabel 2. Kriteria Rata-rata Ideal

\begin{tabular}{lll}
\hline Rentang Skor & Rentangan Skor Real & Kategori \\
\hline $\mathrm{M}_{\mathrm{i}}+1,5 \mathrm{SD}_{\mathrm{i}} \leq M \leq \mathrm{M}_{\mathrm{i}}+3,0 \mathrm{SD}_{\mathrm{i}}$ & $57,05 \leq \mathrm{M} \leq 76,1$ & Sangat tinggi \\
$\mathrm{M}_{\mathrm{i}}+0,5 \mathrm{SDi} \leq M<\mathrm{Mi}+1,5 \mathrm{SD}_{\mathrm{i}}$ & $44,35 \leq \mathrm{M} \leq 57,05$ & Tinggi \\
$\mathrm{M}_{\mathrm{i}}-0,5 \mathrm{SDi} \leq M<\mathrm{Mi}+0,5 \mathrm{SD}_{\mathrm{i}}$ & $31,65 \leq \mathrm{M} \leq 44,35$ & Sedang \\
$\mathrm{M}_{\mathrm{i}}-1,5 \mathrm{SD}_{\mathrm{i}} \leq M<\mathrm{M}_{\mathrm{i}}-0,5 \mathrm{SD}_{\mathrm{i}}$ & $18,95 \leq \mathrm{M} \leq 31,65$ & Rendah \\
$\mathrm{M}_{\mathrm{i}}-3,0 \mathrm{SD}_{\mathrm{i}} \leq M<\mathrm{M}_{\mathrm{i}}-1,5 \mathrm{SD}_{\mathrm{i}}$ & $0,1 \leq \mathrm{M} \leq 18,95$ & Sangat rendah \\
\hline
\end{tabular}

\section{Hasil Dan Pembahasan}

\section{Hasil}

Data penelitian ini adalah skor hasil tes proses kognitif siswa sebagai akibat dari aktivitas pembelajaran mengasosiasi berbasis media gambar berseri pada kelompok eksperimen dan aktivitas pembelajaran konvensional pada kelompok kontrol. Adapun hasil analisis data statistik deskriptif disajikan pada Tabel 3.

Tabel 3 Deskripsi Data Hasil Hasil Tes Proses Kognitif Kelompok Eksperimen dan Kelompok Kontrol

\begin{tabular}{lll}
\hline Statisik & Kelompok Eksperimen & Kelompok Kontrol \\
\hline Skor Tertinggi & 70 & 62 \\
Skor Terendah & 43 & 31 \\
Rentangan & 27 & 31 \\
Mean & 57,15 & 47,68 \\
Median & 58,5 & 47,00 \\
Modus & 63,93 & 40,00 \\
Varians & 72,13 & 89,63 \\
Standar & 8,49 & 9,47 \\
Deviasi & & \\
\hline
\end{tabular}

Berdasarkan Tabel 03, diketahui bahwa mean data hasil tes proses kognitif kelompok eksperimen adalah 57,15 (berada pada kategori sangat tinggi) lebih besar daripada kelompok kontrol yaitu 47,68 (berada pada kategori tinggi).

Sebelum melakukan uji hipotesis maka harus dilakukan beberapa uji prasyarat. Terhadap sebaran data hasil tes proses kognitif yang meliputi uji normalitas terhadap skor post test kelompok eksperimen dan kelompok kontrol dan uji homogenitas varians kedua kelompok. Uji normalitas ini dilakukan untuk membuktikan bahwa kedua sampel tersebut bedistribusi normal.

Berdasarkan hasil perhitungan uji normalitas diperoleh $\chi^{2}$ hit hasil post-test kelompok eksperimen adalah 7,21 dan $\chi^{2}$ tab dengan taraf signifikansi $5 \%$ dan $\mathrm{db}=3$ adalah 7,815. Hal ini berarti, $\chi_{\text {hit }}^{2}$ hasil post-test kelompok eksperimen lebih kecil dari $\chi_{t a b}^{2}\left(\chi_{h i t}^{2}<\chi_{t a b}^{2}\right)$, sehingga data hasil post test kelompok eksperimen berdistribusi normal. Sedangkan, $\chi^{2}$ hit hasil post test kelompok kontrol adalah 7,36 dan $\chi^{2}$ tab dengan taraf signifikansi $5 \%$ dan $\mathrm{db}=3$ adalah 7,815. Hal ini berarti, $\chi^{2}$ hit hasil post-test kelompok kontrol lebih kecil dari $\chi_{t a b}^{2}\left(\chi^{2}{ }_{h i t}<\chi^{2}{ }_{t a b}\right)$, sehingga data hasil post-test kelompok kontrol berdistribusi normal.

Setelah mengetahui hasil uji normalitas, selanjutnya dilakukan uji homogenitas dengan rumus ujiF. Berdasarkan perhitungan uji homogenitas, diketahui $F_{\text {hit }}$ hasil post-test kelompok eksperimen dan kontrol adalah 1,24. Sedangkan $\mathrm{F}_{\text {tab }}$ dengan $\mathrm{db}_{\text {pembilang }}=25, \mathrm{db}_{\text {penyebut }}=27$, dan taraf signifikansi $5 \%$ adalah 1,92. Hal ini berarti, varians data hasil post-test kelompok eksperimen dan kontrol adalah homogen.

Uji hipotesis ini menggunakan uji-t independent "sampel tidak berkorelasi". Di atas telah dipaparkan bahwa data hasil tes proses kognitif kelompok eksperimen dan kelompok kontrol adalah berdistribusi normal dan varians kelompok eksperimen dan kelompok kontrol adalah homogen. Selain itu jumlah siswa pada tiap kelas tidak sama, baik itu kelas eksperimen maupun kelas kontrol, maka pada uji-t 
sampel tak berkorelasi ini digunakan rumus uji-t polled varians. Adapun hasil analisis untuk uji-t dapat disajikan pada Tabel 4.

Tabel 4. Hasil Uji hipotesis

\begin{tabular}{|c|c|c|c|c|c|c|}
\hline Data & Kelompok & $\mathrm{N}$ & $\bar{X}$ & $\mathrm{~s}^{2}$ & thit & $\begin{array}{l}\text { tab (t.s. } \\
5 \%)\end{array}$ \\
\hline $\begin{array}{l}\text { Hasil Tes Proses } \\
\text { Kognitif }\end{array}$ & $\begin{array}{l}\text { Eksperimen } \\
\text { Kontrol }\end{array}$ & $\begin{array}{l}26 \\
28\end{array}$ & $\begin{array}{l}57,15 \\
47,68\end{array}$ & $\begin{array}{l}72,13 \\
89,63\end{array}$ & 8,58 & 2,00665 \\
\hline
\end{tabular}

Berdasarkan hasil perhitungan uji-t diperoleh $t_{\text {hit }}$ sebesar 8,58. Sedangkan $t_{\text {tab }}$ dengan $d k=$ $26+28-2=52$ dan taraf signifikansi $5 \%$ adalah 2,00665. Hal ini berarti, thit lebih besar dari tab (thit $>$ tab), sehingga $\mathrm{H}_{0}$ ditolak dan $\mathrm{H}_{1}$ diterima. Dengan demikian, dapat diinterpretasikan bahwa terdapat perbedaan proses kognitif antara kelompok siswa yang menggunakan aktivitas pembelajaran mengasosiasi berbasis media gambar berseri dalam pendekatan saintifik dan siswa yang belajar menggunakan aktivitas pembelajaran konvensional dalam pendekatan saintifik pada siswa kelas IV semester genap tahun pelajaran 2016/2017 di SD Kecamatan Sukasada.

\section{Pembahasan}

Hasil penelitian ini menunjukkan bahwa proses kognitif siswa yang dicapai dengan menggunakan aktivitas pembelajaran mengasosiasi berbasis media gambar berseri berbeda dengan siswa yang belajar menggunakan pembelajaran konvensional yang sehari-sehari digunakan di sekolah dalam pembelajaran Kurikulum 2013. Secara deskriptif, kelompok yang menggunakan aktivitas pembelajaran mengasosiasi berbasis media gambar berseri memiliki skor rata-rata hasil proses kognitif sebesar 57,15, sedangkan kelompok yang belajar dengan menggunakan pembelajaran konvensional memiliki skor rata-rata hasil proses kognitif 47,68 . Hal ini menunjukkan proses kognitif siswa yang belajar menggunakan aktivitas pembelajaran mengasosiasi berbasis media gambar berseri lebih tinggi daripada siswa yang belajar menggunakan pembelajaran konvensional.

Hal tersebut didukung oleh temuan dari data lapangan yang memperlihatkan bahwa siswa sudah mampu menjawab soal dari C1 samapai C6 yaitu mengingat, memahami, mengaplikasikan, menganalisis, mengevaluasi, dan mencipta pada dimensi proses kognitif Taksonomi Bloom Revisi. Namun proses kognitif siswa yang menerapkan aktivitas pembelajaran mengasosiasi berbasis media gambar berseri dalam pendekatan saintifik memiliki kecenderungan sebagian besar skor siswa sangat tinggi. Hal ini disebabkan oleh beberapa faktor yaitu Pertama, disebabkan karena perbedaan perlakuan pada langkahlangkah pembelajaran dan proses penyampaian materi. Aktivitas pembelajaran mengasosiasi berbasis media gambar berseri lebih menekankan pada proses penalaran siswa dibantu dengan media gambar berseri, sedangkan pembelajaran konvensional menekankan pada hafalan. Kedua, faktor internal. Berdasarkan temuan yang dilakukan oleh Nihayanti, Kt, Semara, Bagus, \& Surya (2015), bahwa faktor internal sangat mempengaruhi kemampuan mengasosiasi siswa. Oleh karena itu, aktivitas pembelajaran mengasosiasi berbasis media gambar berseri memberikan kebebasan kepada siswa untuk mengembangkan pembelajarannya, sehingga pembelajaran menjadi berpusat kepada siswa (student centered). Selama proses pembelajaran berlangsung semua siswa terlibat dan ikut berpartisipasi aktif. Sedangkan, fungsi guru selama proses pembelajaran berlangsung hanyalah sebagai fasilitator dan motivator. Ketiga, kerjasama. Siswa dituntun untuk meningkatkan kerjasama yang dimiliki pada diri siswa, dan meningkatkan interaksi dengan kerja kelompok. Seperti yang diungkapkan oleh Sari, Agung \& Widiana (2015) salah satu faktor penting yang mempengaruhi hasil belajar adalah pemilihan pendekatan pembelajaran yang ditetapkan oleh guru. Oleh sebab itu, pembelajaran harus diarahkan agar dapat membangkitkan kreativitas siswa tersebut salah satunya adalah belajar dengan cara berkelompok. Selain faktor tersebut, dalam aktivitas pembelajaran mengasosiasi berbasis media gambar berseri, guru menggunakan ceramah seperlunya apabila ada siswa yang belum mengerti, tetapi guru hanya membantu mengarahkan kognitif siswa supaya lebih tertata dengan benar sampai siswa paham dan mengerti mengenai materi yang dipelajari.

Hasil penelitian juga didukung oleh hasil penelitiannya Machin (2013) menemukan bahwa dengan menerapakan pendekatan saintifik mampu memperbaiki hasil belajar kognitif, afekif dan psikomotorik bila dibandingkan dengan pembelajaran yang berlangsung sebelumnya. Melalui pendekatan ini peserta didik merasa tertantang dalam pembelajaran yang berdampak pada belajar biologi yang meningkat. Dewi, Anastasia Endah Anastika (2016) menemukan bahwa kedinamisan materi sangat mendorong peserta didik untuk dapat mengasosiasikan segala informasi yang telah didapatkan dengan pengetahuan-pengetahuan baru yang nantinya muncul dalam kegiatan pembelajaran selanjutnya. 
Berdasarkan temuan tersebut, aktivitas pembelajaran mengasosiasi berbasis media gambar berseri dalam pendekatan saintifik dipandang perlu untuk diterapkan dalam pembelajaran, hal ini dikarenakan aktivitas pembelajaran mengasosiasi berbasis media gambar berseri melibatkan peran siswa secara aktif yang dilakukan secara berkelompok untuk menyelesaikan suatu masalah yang diberikan dan menyampaikan hasil yang diperoleh dalam pembelajaran serta mampu meningkatkan proses kognitif yang dimiliki siswa.

Aktivitas pembelajaran mengasosiasi berbasis media gambar berseri dalam pendekatan saintifik sudah sesuai dengan karakteristik siswa Sekolah Dasar kelas tinggi yang berada pada tahap operasional konkret. Hal tersebut terlihat dari antusiasme siswa untuk dapat melihat, berbuat sesuatu, melibatkan diri dalam pembelajaran, serta mengalami langsung pada hal-hal yang dipelajari. Siswa sangat berminat dengan materi-materi yang dikemas khusus sesuai dengan kehidupan sehari-hari oleh guru, dan siswa diajak bermain selama proses pembelajaran. Hal ini didukung oleh Piaget yang mengemukakan bahwa siswa SD berada pada tahap operasional konkret (7 hingga 11 tahun), dimana konsep yang ada pada awal usia ini adalah konsep yang samar-samar dan sekarang lebih konkret.

Dalam proses pembelajaran konvensional, guru masih berusaha memindahkan pengetahuan yang dimilikinya kepada siswa. Pada saat kegiatan pembelajaran berlangsung, siswa duduk dengan tenang dan memperhatikan guru menjelaskan materi pelajaran. Hal seperti ini justru mengakibatkan guru sulit mengetahui pemahaman siswa, karena siswa yang belum mengerti cenderung malu untuk bertanya. Selanjutnya guru menyuruh siswa untuk membaca cerita yang ada di buku dan menyuruh siswa untuk membacakan ke depan kelas. Ketika siswa membaca di depan kelas, siswa yang lain tidak ada yang mendengarkan dan cenderung ribut dengan teman sebangkunya. Di akhir pembelajaran guru membantu siswa untuk merefleksi kembali materi yang telah dipelajari, kemudian memberikan pekerjaan rumah (PR). Situasi pembelajaran tersebut membuat siswa pasif dalam menerima pelajaran, sehingga daya pikir siswa tidak berkembang secara optimal. Kondisi ini membuat siswa tidak termotivasi mengikuti pembelajaran dan sulit mengembangkan ketrampilan berpikirnya. Hal ini menyebabkan rendahnya proses kognitif siswa.

Hasil penelitian ini menguatkan beberapa hasil penelitian yang ditemukan belakangan ini, diantaranya penelitian yang dilakukan oleh Waty, Rustini, \& Sundari, n.d. (2015) bahwa proses pembelajaran siswa dengan menggunakan pendekatan saintifik pada saat penelitian dilakukan dari setiap siklusnya telah mengalami peningkatan kearah yang lebih baik. Hasil penelitian lain juga menunjukkan bahwa ada perbedaan yang signifikan antara hasil belajar siswa yang belajar dengan pendekatan ilmiah yang didasarkan pada penilaian portofolio dalam hal objek konkret dan siswa yang belajar dengan pendekatan ilmiah yang didasarkan pada penilaian portofolio dalam hal benda konkret di kelas V di semester 2 tahun akademik 2014/2015 (Agusditya, Asri, \& Suara, 2017). Selain menguatkan hasil penelitian yang menerapkan pendekatan saintifik, hasil penelitian ini juga menguatkan hasil penelitian yang menerapkan media gambar berseri. Pemanfaatan media gambar berseri dalam pembelajaran tematik bertema pekerjaan dapat meningkatkan keterampilan menulis karangan siswa kelas III SDN Tlanak III Kedungpring Lamongan (Putri, Sisca Pradini Olyvia, 2013). Penggunaan media gambar berseri juga meningkatkan keterampilan menulis narasi siswa kelas IV SDN Tambak Kemeraan Kecamatan Krian (Susanti, Apriliya, Hariani, 2013). Hal ini dibuktikan pada hasil belajar siswa menunjukkan ketuntasan belajar pada siklus I sebesar 53,57\% dan mengalami peningkatan pada siklus II sebesar $82,14 \%$.

Uraian di atas memberikan gambaran bahwa aktivitas pembelajaran mengasosiasi berbasis media gambar berseri telah mampu memberikan kontribusi yang positif dalam meningkatkan hasil proses kognitif siswa. Selain itu, tidak hanya meningkatkan aktivitas siswa secara individu, tetapi juga terhadap anggota kelompok sehingga dapat mengoptimalkan kerja sama antar kelompok. Aktivitas pembelajaran mengasosiasi berbasis media gambar berseri dapat dijadikan satu alternatif pembelajaran yang kreatif dan inovatif dalam upaya peningkatan mutu pendidikan khususnya dalam kurikulum 2013.

\section{Simpulan dan Saran}

Penelitian ini menemukan bahwa terdapat perbedaan yang signifikan proses kognitif antara kelompok siswa yang belajar dengan aktivitas pembelajaran mengasosiasi berbasis media gambar berseri dan kelompok siswa yang belajar dengan menggunakan pembelajaran konvensional pada Kurikulum 2013 kelas IV SD di Kecamatan Sukasada. Perbedaan ini ditinjau dari rata-rata skor proses kognitif siswa dan hasil uji-t. Rata-rata skor proses kognitif siswa yang mengikuti aktivitas pembelajaran mengasosiasi berbasis media gambar berseri adalah 57,15 dan rata-rata skor proses kognitif siswa yang mengikuti pembelajaran konvensional adalah 47,68 (X eksperimen $>\bar{X}$ kontrol). Selanjutnya berdasarkan hasil perhitungan uji-t, diperoleh thit sebesar 8,58 sedangkan tab dengan $\mathrm{db}=52$ pada taraf signifikansi $5 \%$ adalah 2,00665. Hal ini berarti, thit lebih besar dari $\mathrm{t}_{\text {tab }}$ ( $\mathrm{t}_{\text {hit }}>\mathrm{t}_{\mathrm{tab}}$ ), sehingga $\mathrm{H}_{0}$ ditolak dan $\mathrm{H}_{1}$ diterima. 
Dengan demikian aktivitas pembelajaran mengasosiasi berbasis media gambar berseri berpengaruh terhadap proses kognitif siswa.

Berdasarkan hasil penelitian dan simpulan tersebut, dapat dikatakan bahwa tujuan penelitian dalam penelitian ini telah tercapai. Oleh karena itu disarankan kepada guru-guru hendaknya dapat menjadikan aktivitas pembelajaran mengasosiasi berbasis media gambar berseri menjadi salah satu aktivitas pembelajaran yang harus diterapkan dalam pembelajaran. Tidak hanya aktivitas tersebut, namun aktivitas-aktivitas pembelajaran dalam pendekatan saintifik lainnya juga lebih ditingkatkan lagi agar kegiatan pembelajaran lebih inovatif dan tidak berkesan membosankan bagi peserta didik. Penelitian ini juga dapat dijadikan refrensi untuk melakukan penelitian lebih lanjut dengan materi atau pokok bahasan yang berbeda, tingkatan kelas yang berbeda, dan tambahan variabel baru sebagai kreativitas baru.

\section{Daftar Pustaka}

Agusditya, P. H., Asri, I. G. A. A. S., \& Suara, I. (2017). The Effect of Scientific Approach Based on Portfolio Assessment towards the Learning Outcomes of Civic Education of the Students Grade V Viewed from the Tendency of Observing Objects on Theme 7 SDN 4 Ubung, 1, 91-99.

Almasitoh, U. H. (2013). Pengaruh Media Gambar Berseri dalam Meningkatkan Kemampuan Mengarang Narasi.

Anderson Larin \& Krathwohl David. 2010. Pembelajaran, Pengajaran, Dan Asesmen. Yoyakarta: Pustaka Belajar.

Apriliani, Ni Kadek Winda Ni Nyoman Ganing, I Wayan Wiarta. 2016. Pendekatan Saintifik Berbantuan Media Gambar Berseri Berpengaruh Terhadap Keterampilan Menulis Siswa Kelas I SD. e-Journal PGSD Universitas Pendidikan Ganesha Jurusan PGSD Vol: 4 No: 1.

Ariningsih, K., Suwatra, I. W., \& Widiana, I. W. (2015). Analisis Diskrepansi Pembelajaran Dengan Kurikulum, (2).

Aristana, P. N. E., Kusmariyatni, N. N., \& Widiana, I. W. (2014). Pengaruh Model Pembelajaran Mandiri Berbantuan Media Gambar Terhadap Kemampuan Berpikir Kritis IPA pada Siswa Kelas V SD. Universitas Pendidikan Ganesha.

Dewi, Anastasia Endah Anastika \& Mukminan. (2016). Implementasi Pendekatan Saintifik dalam Pembelajaran IPS di Middle Grade SD Tumbuh 3 Kota Yogyakarta, 4, 20-31.

Dewi, Metta Anugrah, Sumantri \& Widiana, I. W. (2015). Diskrepansi Pembelajaran Kurikulum 2013 Berdasarkan Permendikbud No. 65 Tahun 2013 di SD No. 4 Kampung Baru Jurusan Pendidikan Guru Sekolah Dasar , FIP Universitas Pendidikan Ganesha e-Journal PGSD Universitas Pendidikan Ganesha, (65).

Krissandi, Apri Damai Sagita, R. (2013). Kendala Guru Sekolah Dasar dalam Implementasi Kurikulum 2013, 457-467.

Kristiantari, M. R. (2014). Analisis Kesiapan Guru Sekolah Dasar dalam Mengimplementasikan Pembelajaran Tematik Integratif Menyongsong Kurikulum 2013, 3(2), 460-470.

Kurniasih, Imas dan Berlin Sani. 2015. Sukses Mengimplementasikan Kurikulum 2013.Yogyakarta: Kata Pena

Machin, A. (2013). Implementasi Pendekatan Saintifik, Penanaman Karakter Dan Konservasi Pada Pembelajaran Materi Pertumbuhan. Jurnal Pendidikan IPA Indonesia, 2(2), 203-208.

Mahendra, K. A., Arini, N. W., \& Sumantri, M. (2016). Media Gambar Berseri Terhadap Keterampilan Berbicara Siswa Kelas IV SDN 1 Sangsit.

Nihayanti, Semara, D. B. K. N., \& Abadi, I. B. G. S. (2015). Proses Pembelajaran dengan Pendekatan Saintifik Pada Di Kelas II SD Negeri 14 Dauh Puri Jurusan Pendidikan Guru Sekolah Dasar , FIP Universitas Pendidikan Ganesha, 2013(1).

Oktafianti, Elly. 2015. Pelaksanaan Pembelajaran Berbasis Pendekatan Saintifik Di Kelas Ib Sd Negeri Pujokusuman 1 Yogyakarta. Jurnal Pendidikan Guru Sekolah Dasar Edisi 9 Tahun ke IV Mei 2015.

Puspitarukmi, P. S., Fuady, A., \& Wardani, N. E. (2014). Pemanfaatan media gambar berseri dengan metode Teams Games Tournament (TGT) untuk Meningkatkan Motivasi Belajar dan Keterampilan Menulis Eksposisi, I(April), 551-561.

Putra, Made dan Ni Wayan Suniasih 2015. Kemampuan Merancang Dan Melaksanakan Pembelajaran Sesuai Kurikulum 2013 Melalui Kaji Tindak Pembelajaran. Vol 48, No 1-3 tersedia di https://ejournal.undiksha.ac.id/index.php/JPP/issue/view/417.

Putra, I Gede Dharma dan Putu Nanci Riastini. 2016. Analisis Kesenjangan Perencanaan Dan Pelaksanaan Pembelajaran Kurikulum 2013 Di Sdn 4 Kampung Baru. Vol 49, No 1 tersedia di https://ejournal.undiksha.ac.id/index.php/IPP/issue/view/532. 
Putri, Sisca Pradini Olyvia, M. (2013). Pemanfaatan Media Gambar Berseri untuk Peningkatan Keterampilan Menulis Karangan Siswa Sekolah Dasar, 2013,1-10.

Sari, Putu Desi Ratna, Agung, Anak Agung Gede, Widiana, I. W. (2015). Pengaruh Pendekatan Saintifik dan Kepercayaan Diri, (2).

Subagia, I Wayan, Wiratma, I. G. L. (2016). Profil Penilaian Hasil Belajar Siswa Berdasarkan Kurikulum 2013, 5(1), 725-738.

Sugiarti, N. L. P. Y., Putra, I. K. A., \& Abadi, I. B. G. S. (2014). Pengaruh Model Pembelajaran TTW (Think Talk Write) Berbantuan Media Gambar Berseri Terhadap Keterampilan Menulis Bahasa Indonesia Siswa Kelas V SD Gugus 1 Kecamatan Kediri Tahun Ajaran 2013 / 2014 Jurusan Pendidikan Guru Sekolah Dasar , FIP Universitas, 2(1).

Sumerti, N. L., Putra, I. K. A., \& Suardika, I. W. R. (2014). Pengaruh Model Pembelajaran Kooperatif Tipe Concept Sentence Berbantuan Gambar Berseri Terhadap Keterampilan Menulis Siswa Kelas V SDN 22 Dauh Puri Jurusan Pendidikan Guru Sekolah Dasar , FIP Universitas Pendidikan Ganesha Singaraja, Indonesia e-Journal Mimbar PGSD Universitas Pendidikan Ganesha Jurusan PGSD ( Vol : 2 No : 1 Tahun 2014 ).

Sumantri, Made, Dewa Nyoman Sudana, I. B. Eka Yoni Adnyana P. 2017. Penerapan Media Gambar Dan Kartu Huruf Untuk Meningkatkan Keterampilan Membaca Permulaan. Vol 1 no 1 tersedia di https://ejournal.undiksha.ac.id/index.php/IJEE/issue/view/694.

Suryantari, K. D., \& Sumantri, M. (2014). Analisis Kesenjangan Perencanaan dan Pelaksanaan Pembelajaran Kurikulum 2013 di SD Negeri 4 Kaliuntu, (103), 59-69.

Susanti, Apriliya, Hariani, S. (2013). Penggunaan Media Gambar Berseri untuk Meningkatkan Keterampilan Menulis Narasi Siswa Kelas IV SDN Tambak Kemeraan Kecamatan Krian Apriliya Susanti, 1-11.

Wartini, Ida Ayu Km Mirah, Lasmawan, I Wayan, Marhaen, A. A. I. . (2014). Sikap Sosial dan Hasil Belajar Pkn di Kelas VI. E-Journal Program Pascasarjana Universitas Pendidikan Ganesha Program Studi Pendidikan Dasar, 4.

Waty, S., Rustini, T., \& Sundari, N. (n.d.). Pendekatan Saintifik untuk Meningkatkan Kemampuan Komunikasi Kolaboratif Siswa dalam Pembelajaran IPS di Kelas IV SD, (1), 1-13.

Wicaksosno, Lugas. 2012. Sekolah di Buleleng Tetap Terapkan Kurikulum 2013. Bali.tribunnews.com.

Widyani, Luh Ni Sadewi, Suwatra, I. I. W., \& Widiana, I. W. (2017). The Discrepancy of Curriculum 2013 in Teaching and Learning Process Based on Permendikbud No 65 of 2013 in SD Laboratorium Undiksha, 1(65), 57-64. 